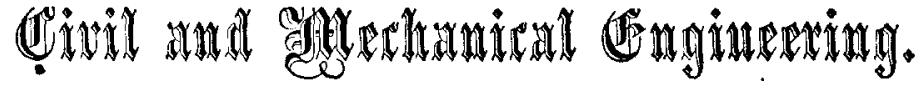

\section{FORMULAS AND TABLES FOR THE SHAFTING OF MILLS AND FACTORIES.}

By James B. Francis, Civil Engineer.

THE following investigation was undertaken at the request of General John C. Palfrey, the Agent of the Merrimack Manufacturing Company, of Lowell, Massachusetts, for the purpose of determining the relative fitness of wrought iron and steel for the shafting of a cotton factory now erecting by that company.

Samples of steel, all of American manufacture, were obtained from different makers, and, together with several samples of iron, were subjected to experiment.

The constant expressing the resistance of cylindrical bars to torsion, I deduce from Navier's formula,*

in which,

$$
A=\frac{16 \mathrm{w} \mathrm{R}}{\pi d^{s^{-}}, . . .} \cdot .
$$

$T=\mathbf{a}$ constant for the same material.

$\mathrm{W}=$ the weight, in pounds, which, if applied at the distance $\mathbf{R}$, in inches, from the axis, will just fracture the bar.

$\pi=$ the ratio of the circumference of a circle to its diameter.

$d=$ the diameter, in inches, of the bar at the place of fracture.

The bars subjected to torsion, were finished in the form of the following diagram; the ends being two inches square, and the middle turned down to a diameter of $\frac{3}{4}$ inch, in order to insure the fracture taking place in that part of the bar.

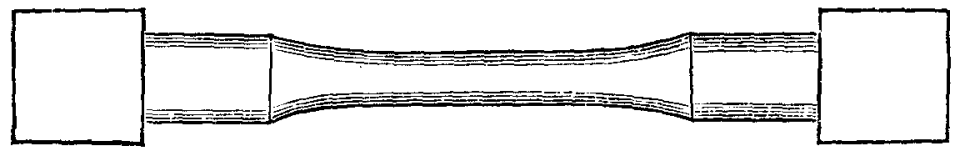

The weight producing the torsion was applied at the end of a lever, of the effective length of 35.975 inches, fitted to the square boss at one end of the bar. The tendency of the bar to revolve

* Resumé des Legons sur l'application de la mécanique. 
under the action of the weight, was controlled by a worm-wheel about fifteen inches in diameter and one hundred and thirty-eight teeth, fitted to the square boss at the other end of the bar. This wheel could be moved through any arc by means of a worm. As the bar became twisted by the torsional strain, the worm-wheel was moved through an arc sufficient to bring the lever to an horizontal position.

A graduated circle on one face of the worm-wheel, furnished the means of measuring the arc of torsion.

The effective weight of the lever and scale at 35.975 inches from the axis, where the scale was hung on a knife edge, was 48.5 pounds, and was the least effective weight which could be applied to produce torsion.

EXPERIMENTS ON TORSION.

\begin{tabular}{|c|c|c|c|c|c|}
\hline DESCRIPTION OF TIIE BAR. & 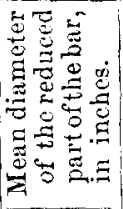 & 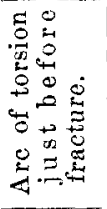 & 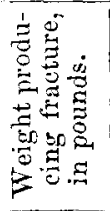 & 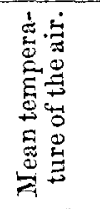 & $\begin{array}{l}\text { Value } \\
\text { of } \\
\mathbf{T}\end{array}$ \\
\hline \multirow{2}{*}{\multicolumn{6}{|c|}{$\begin{array}{l}\text { English refined wroughtiron, from } \\
\text { a bar two inches in diameter, } \\
\text { marked } A, 13 \ldots \ldots \ldots \ldots \ldots \ldots \ldots \ldots . . . . . . . . . .\end{array}$}} \\
\hline & 0.750 & $416.8^{\circ}$ & $113 \cdot 17$ & $58 \cdot 8^{\circ}$ & 49,148 \\
\hline 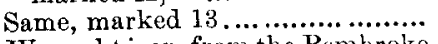 & 0.750 & $596 \cdot 0^{\circ}$ & $125 \cdot 69$ & $66 \cdot 0^{\circ}$ & 54,585 \\
\hline Wrought iron, from the Pembroke & & & & & \\
\hline Iron Works, Maine, marked 14 & 0.753 & $641 \cdot 3^{\circ}$ & $143 \cdot 72$ & $62 \cdot 3^{\circ}$ & 61,673 \\
\hline $\begin{array}{l}\text { Decarbonized steel, from the farist } \\
\text { Steel Company, Windsor Locks, } \\
\text { Conn, from a bar two inches }\end{array}$ & & & & & \\
\hline $\begin{array}{l}\text { square, marked } B, 6 \ldots \ldots \ldots \ldots . . \\
\text { Spindle steel, from the same, from }\end{array}$ & 0.752 & $390 \cdot 5^{\circ}$ & $192 \cdot 48$ & $70 \cdot 2^{\circ}$ & 82,926 \\
\hline a bar two inches square, marked & 0.750 & $284 \cdot 3^{\circ}$ & $235 \cdot 17$ & $68 \cdot 3^{\circ}$ & 102,131 \\
\hline $\begin{array}{l}\text { Steel, from the Nashua Iron Co., } \\
\text { Nashua, N. H., from a bar two }\end{array}$ & & & & & \\
\hline inches square, marked $2 . . . \ldots$.. & 0.751 & $611 \cdot 3^{\circ}$ & $198 \cdot 73$ & $65.5^{\circ}$ & 85,901 \\
\hline $\begin{array}{l}\text { Same, marked } d, 2, \ldots \ldots \ldots \ldots \ldots \ldots \\
\text { Steel, from same, from if inch }\end{array}$ & 0.752 & $557 \cdot 0^{\circ}$ & 20323 & $63.7^{\circ}$ & 87,557 \\
\hline $\begin{array}{l}\text { Steel, from same, from } 11 \text { inch } \\
\text { octagonal bar, marked } 4 \ldots \ldots .\end{array}$ & $0 \cdot 752$ & $475 \cdot 0^{\circ}$ & $221 \cdot 0$ & $67 \cdot 5^{\circ}$ & 95,213 \\
\hline Same, marked $3 \ldots \ldots \ldots \ldots . . . . . . . . .$. & $0 \cdot 751$ & $508 \cdot 3^{\circ}$ & $217 \cdot 25$ & $61 \cdot 2^{\circ}$ & 98,972 \\
\hline $\begin{array}{l}\text { Steel, from the works of Hussey, } \\
\text { Wells \& Co, Pitts burgh, from } \\
\text { a bar two inches square, marked }\end{array}$ & & & & & \\
\hline 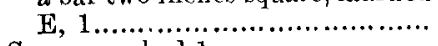 & $0 \cdot 751$ & $398 \cdot 10^{\circ}$ & $202 \cdot 66$ & $63 \cdot 6^{\circ}$ & 87,661 \\
\hline $\begin{array}{l}\text { Same, marked } 1 \text {.......................... } \\
\text { Bessemer steel, from the works of }\end{array}$ & 0.748 & $207 \cdot 3^{\circ}$ & $196 \cdot 50$ & $68 \cdot 0^{\circ}$ & 86,023 \\
\hline $\begin{array}{l}\text { Bessemer steel, from the works of } \\
\text { Messrs. Winslow \& Griswold, } \\
\text { Troy, N. Y., from a bar two }\end{array}$ & & & & & \\
\hline $\begin{array}{l}\text { Troy, } N \text {. Y., from a bar two } \\
\text { inches square, marked } 16 \ldots \ldots . . . .\end{array}$ & 0.748 & $215 \cdot 5^{\circ}$ & $181 \cdot 97$ & $66 \cdot 0^{\circ}$ & 79,662 \\
\hline 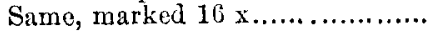 & 0.748 & $208 \cdot 5^{\circ}$ & $174 \cdot 50$ & $67 \cdot 0^{\circ}$ & 76,392 \\
\hline
\end{tabular}


The experiments on deflection were made on round bars turned to a diameter of about one inch. The distance between the points of support was forty-eight inches. Observations were made of the deflections produced by a weight of one hundred and fifty pounds suspended at the middle point between the supports. This weight was not sufficient to cause any sensible set in the bar after the weight was removed; and no sensible increase in the deflection was produced by allowing the weight to remain suspended on the bar for several days.

The constant $\mathrm{E}$ for deflection, has been computed by Navier's formula, ${ }^{*}$

in which

$$
s=\frac{l^{3} \mathrm{~W}}{6 \pi d^{-1} \mathrm{E}}, \cdot . \quad \cdot \quad \cdot \quad \cdot .
$$

$l=$ the distance between the points of support, in inches.

$w=$ the weight at the middle point between the supports, in pounds.

- $\pi=$ the ratio of the circumference of a circle to its diameter.

$d=$ the diameter of the bar, in inches.

$s=$ the deflection at the middle point between the supports, in inches.

EXPERIMENTS ON DFFLECTION.

\begin{tabular}{|c|c|c|c|c|}
\hline DESCRITTION OF THE IBAR. & 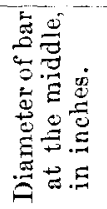 & 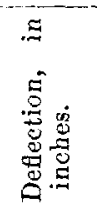 & 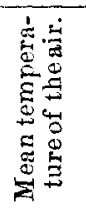 & $\begin{array}{l}\text { Value } \\
\text { of } \\
\mathbf{E}\end{array}$ \\
\hline $\begin{array}{l}\text { Spindle steel, from the Farist Steel Co., } \\
\text { Windsor Locks, Conn., from a bar } 11-16 \\
\text { inches in diameter, marked A, } 7 . \ldots \ldots \ldots . .\end{array}$ & .995 & 0.2330 & $48 \cdot 0^{\circ}$ & $3,853,590$ \\
\hline 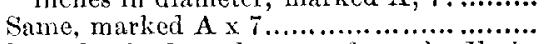 & 0.977 & 0.2315 & $53 \cdot 8^{\circ}$ & $3,847,530$ \\
\hline $\begin{array}{l}\text { Decarbonized steel, extra, from the Farist } \\
\text { Steel Co., from a bar } 11-16 \text { inches in } \\
\text { diameter, marked A A X................... }\end{array}$ & 0.993 & 0.2310 & $53.0^{\circ}$ & $3,918,360$ \\
\hline 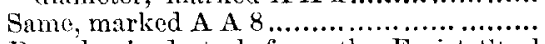 & 0.995 & 0.2327 & $53 \cdot 7^{\circ}$ & $3,858,557$ \\
\hline 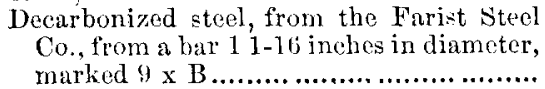 & .092 & 0.2330 & $54 \cdot 2^{\circ}$ & $3,900,420$ \\
\hline 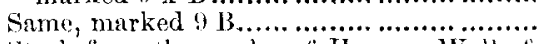 & 0.995 & $0 \cdot 2307$ & $53 \cdot 3^{\circ}$ & $3,892,008$ \\
\hline $\begin{array}{l}\text { Steel, from the works of Hussey, Wolls } \mathrm{d} \\
\text { Co., Pittsburgh, from a bar } 11-16 \text { inches }\end{array}$ & & & & \\
\hline ked 15. & 998 & 0.2837 & $52 \cdot 2^{\circ}$ & $3,796,060$ \\
\hline 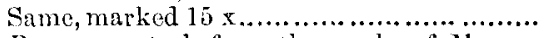 & 0.996 & 0.2387 & $49 \cdot 8^{\circ}$ & $3,826,641$ \\
\hline 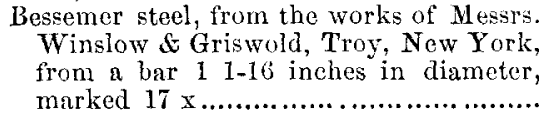 & $1 \cdot 000$ & $0 \cdot 2820$ & $49 \cdot 4^{\circ}$ & $3,777,095$ \\
\hline 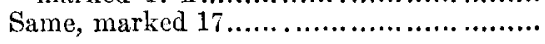 & $1 \cdot 000$ & 0.2315 & $52 \cdot 0^{\circ}$ & $3,801,566$ \\
\hline
\end{tabular}

* See the number of this Journal for February, 1862. 
Several specimens of the steel have been tested for tensile strength, at the works of the South Boston Iron Company, by Mr. F. Alger, in the apparatus designed by Major W. Wade, for testing metals for cannon, a description of which may be found in Reports of Experiments on the Strength and other Properties of Metals for Cannon, published in 1854, by authority of the Secretary of War.

EXPERTMENTS ON TENSILE STRENGTH.

\begin{tabular}{|c|c|c|c|c|}
\hline DESCRIPTION OF THE SPECIMEN. & 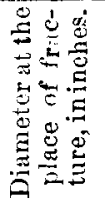 & 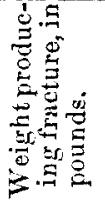 & 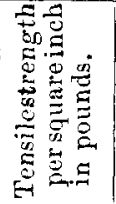 & $\begin{array}{l}\text { Specific } \\
\text { Gravity. }\end{array}$ \\
\hline $\begin{array}{l}\text { Spindle steel, from the Farist Stecl Co., } \\
\text { Windsor Locks, Conn., marked A } 10 \\
\text { A } 1 \ldots \ldots \ldots \ldots \ldots \ldots \ldots \ldots \ldots \ldots \ldots \ldots \ldots \ldots \ldots \ldots \ldots \ldots \ldots \ldots \ldots \ldots\end{array}$ & $0.59 \pi$ & 40.800 & 145.754 & $7 \cdot 8401$ \\
\hline 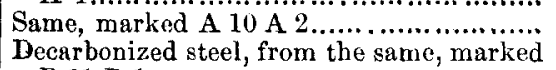 & 0598 & 39,500 & 140,639 & $7 \cdot 8287$ \\
\hline 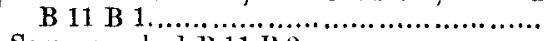 & $0 \cdot 596$ & 34,500 & 128,662 & $7 \cdot 8583$ \\
\hline $\begin{array}{l}\text { Same, marked } \mathrm{B} 11 \mathrm{~B} 2 \ldots \ldots \ldots \ldots \ldots \ldots \ldots \ldots \\
\text { Decarbonized steel, extra, from the same, }\end{array}$ & 0.597 & 35,200 & 125,750 & $7 \cdot 8514$ \\
\hline $\begin{array}{l}\text { Decarbonized steet, extra, from the same, } \\
\text { marked A A x } 1 \ldots \ldots \ldots \ldots \ldots \ldots \ldots \ldots \ldots \ldots \ldots \ldots \ldots\end{array}$ & $0 \cdot 600$ & $30,5,50$ & 107,862 & $7 \cdot 8417$ \\
\hline $\begin{array}{l}\text { Same, marked A A } \times 2 \ldots \ldots \ldots \ldots \ldots \ldots \ldots \ldots \ldots \ldots \ldots \ldots \ldots \\
\text { Same, marked A A } x \text {; ends upset in order }\end{array}$ & $0 \cdot 600$ & 30,40, & $109 \cdot \pm 71$ & $7 \cdot 8579$ \\
\hline $\begin{array}{l}\text { to form the specimen ................................. } \\
\text { Same as next preceding specimen, marke }\end{array}$ & $0 \cdot 600$ & 30,890 & 108,901 & 7.8484 \\
\hline $\begin{array}{l}\text { Same as next preceding specimen, marked } \\
\mathbf{A} \mathbf{A} \times 2 \ldots \ldots \ldots \ldots \ldots \ldots \ldots \\
\text { Steel, from the works of Husser. Wolls } \&\end{array}$ & 0.600 & 29,700 & 105,053 & $7 \cdot 8534$ \\
\hline Co., Pittsburgh, marked c $12,1 . . . . . . . .$. & 0.594 & 40,400 & 145,790 & $7 \cdot 8530$ \\
\hline Same, marked c $12,2, \ldots \ldots \ldots \ldots \ldots \ldots \ldots \ldots$ & $0 \cdot 594$ & 40,200 & 145,070 & $7 \cdot 8496$ \\
\hline
\end{tabular}

I find on record many experiments on the fracture of iron and steel by torsion, from which $\mathrm{I}$ deduce the following values of $\mathrm{T}$; using the above formula for cylindrical bars, and Navier's formula,

$$
T=\frac{3 \sqrt{2} w_{R}}{b^{3}}, . \quad . \quad . \quad . \quad .
$$

for square bars, in which $b=$ the side of the square in inches, and $w$ and $\mathrm{R}$ the weight in pounds, producing fracture, and the distance from the axis in inches, at which it is applied.

Experments By Rennie, given in the Philosophical Transactions of the Royal Society, for 1818.

Bar of English wrought iron, 0.25 inch square, ........T $=65,982$

Bar of Swedish $\quad$ " $\quad 0.25 \quad$ “ $\quad \ldots \ldots . . T=61,909$

Bar of shear stecl, $\quad 0.25 \quad$ " $\quad \ldots \ldots . . T=111,191$

Average of 3 bars of iron east horizontally, $0.25 \mathrm{in}$. sq., $\mathrm{T}=64,776$ 
Expertments given in the fifth edition of Haswell's Engineers' and Mechanics' Pocket Book.

Bar of Ulster Iron Co.'s wrought iron, one inch diameter, $\mathrm{T}=87,090$

Bar of Swedish " " $\quad$ " $\quad \mathrm{T}=93,965$

Experiments made at the Royal Gun Factories, Woolwich, England, on many varieties of cast iron. Parliamentary Document ordered to be printed July 30,1858 .

Experiments are given on fifty-one varieties of British cast iron, besides several varieties from other countries. I select the experiments on four varieties of British iron, viz: the strongest, two of medium strength, and the weakest; each result being deduced from a mean of several experiments on bars about 1.8 inch in diameter.

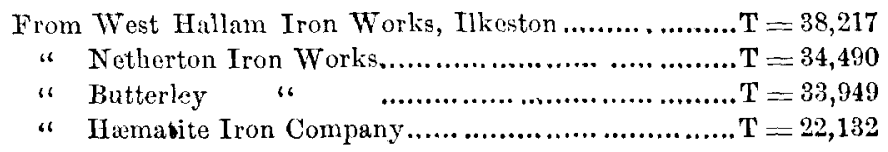

Expraments made at the Fort Pitt Foundry, in 1846, on bars of different forms and dimensions, of common foundry iron, given in Reports of Experiments, Sc., above eited.

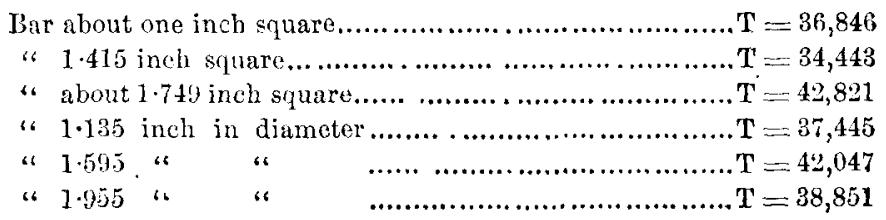

EXPERIMENTS made at the West Point Foundry, in 1851, on Greenwood iron of difforent grades, mixtures and fusions, given in Reports of Experiments, \&c., above cited.

Mean deduced from eighteen experiments on bars about 1.9 inches diameter $\mathrm{T}==4.4,957$

The value of $\mathrm{E}$, for wrought iron, I have previously deduced from English experiments, and tested by a single experiment on a shaft two inches in diameter and about 180 inches between bearing.** From these experiments I find ......................E $=3,492,589$

There being such great irregularities in the values of $\mathrm{T}$, it will not be safe, in practice, to take a mean value, but one near the lowest value.

* See the number of this Journal for Eubruary, 186:. 
The values for wrought iron vary from 49,148 to 93,965 . For safety,

I take for wrought iron ..............................T $=50,000$

The values for steel vary from 76,392 to 111,191 . For safety, I take for steel........................................ $\mathrm{T}=80,000$

The values for cast iron vary from 22,132 to 64,776 . For safety, I take for cast iron ................................. $\mathrm{T}=30,000$

I also take for wrought iron........................ $\mathrm{E}=8,500,000$

And for untempered steol.....................

Shafts for transmitting power, are subject to two forces, viz: transverse strain and torsion. In shafts of wrought' iron or stelel, in which the bearings are not very near to each other, a transverse strain, too small to cause fracture, will produce sensible deflection; if this is too great, it will produce sensible irregularities in the motion, and tend towards the rapid destruction of the shaft and its bearings. This limits the distance between the bearings, as the weight of the shaft itself will produce an inadmissible amount of deflection whenever this distance exceeds a certain amount, which varies with the material and diameter of the shaft.

The deflection of a cylindrical shaft from its own weight, supported at each end, but disconnected from other shafts, is given by the formula (4), which is deduced from Navier's formula for the deflection of a cylindrical bar. See Journal of the Franklin Institute for February, 1862.

$$
\grave{c}=0.007318 \frac{l^{4}}{d^{2} \mathrm{E}}, \cdot . \quad . \quad .
$$

If the several parts are so connected as to be equivalent to one continuous shaft, it will correspond to the case of a beam fixed at both ends, for which case Barlow* gives a equal to two-thirds of its value in the case of a beam supported at both ends, given by formula (4). Naviert, taking into account the effect of the deflection in the adjacent divisions, finds $\delta$ equal to one-fourth of its value by formula (4). In order to decide which of these eminent authorities to follow, I have appealed to experiment.

Experiment 1. A bar of wrought iron purchased as "English refined," 12 feet 23 inches long, 0.367 inch deep, 1.535 inch wide, was supported at four equidistant points, four feet apart. When loaded at the middle points of each division with fifty-two pounds, the deflection in the middle division was $0.069 \mathrm{inch}$, and the

\footnotetext{
* Report of the third meeting of the British Association for the Advancement of Science.

† Résume des legons sur l'application de la mócanique.
} 
mean deflection in the other two divisions was 0.371 inch. The weight on the middle division was then increased until the deflection was alike, viz: 0.281 inch in each division; the weight being 82.84 pounds in the middle division, and $52: 00$ pounds in each of the other divisions. Four feet was then cut off of each end of the bar, when the deflection, with 82.84 pounds on the middle division, was 1.102 inch.

Experiment 2. A bar of iron of the same quality and length as in experiment 1, 0.551 inch square, was laid on the same supports. When loaded at the middle points of each division with fifty-two pounds, the deflection in the middle division was $0.058 \mathrm{inch}$, and the mean deflection in the other two divisions was 0.314 inch. The weight on the middle division was then increased until the deflection was 0.241 inch in each division; the weight being 82.84 pounds in the middle division, and 52.00 pounds in each of the other divisions. Four feet was then cut off of each end of the bar, when the deflection, with 82.84 pounds on the middle division, was 0.984 inch.

In the case in which the deflections were alike in the three divisions, the middle division corresponds to the case of a continuous shaft supported by numerous equidistant bearings, and the case where the bar was reduced in length, corresponds to that in formula (4). Comparing the deflections in the two cases in the above experiments, we find by experiment 1 , that the ratio of the deflection of the shaft, simply supported at each end, to that of the continuous shaft, is as 1 to $0 \cdot 255$. In experiment 2 , the corresponding ratio is as 1 to 0.245 ; the mean of the two experiments giving a ratio of 1 to $0 \cdot 25$, * which agrees with Navier, and we must adopt for the deflection of a continuous shaft, from its own weight, the formula

$$
\delta=\frac{1}{4} \times 0.007318 \frac{l^{4}}{d^{2} \mathrm{E}}, \cdot . \quad \cdot .
$$

The greatest admissible value of $\partial$ in proportion to the length, must be determined by experience. Tredgold assumes that for cast iron, it might be 0.01 inch for each foot in length, or ${ }_{I^{1} \bar{z}_{\overline{0}}}$ part of the

* These experiments indicate the effect of connecting the chords of truss bridges over the piers. Assuming that in a bridge of not less than three equal spans, the top and bottom chords have equal resisting powers, and the whole length of the bridge is uniformly loaded, if the chords are continuous throughout the whole length of the bridge, the deflection of any span, except the end spans, will be one quarter of the amount that it would be if the chords were disconnected at tho piers. 
length, whatever may be the diameter; but the transverse strain to produce this deflection, is a greater fraction of the transverse strain that will produce fracture in a large shaft than in a small one. The maximum strains of extension and compression in a shaft, for the same deflection, are in proportion to the diameter, while the deflection itself, from the weight of the shaft, is inversely as the square of the diameter; consequently, the deflection to produce the same maximum strains, must be inversely as the diameter.

Adopting this principle and the assumption that a shaft of wrought iron or untempered steel two inches in diameter, may deflect from its own weight, 0.01 inch per foot in length between the bearings, we may determine the greatest almissible distances between the bearings of shafts of other diameters, as follows:

The greatest admissible deflection for any diameter $d$, is

$$
\delta=\frac{2 l}{1200 d}=0.00167 \frac{l}{d}, \cdot \text {. . . . }
$$

Substituting this value of $\delta$ in (5) and reducing, we have

$$
l=30.9128 d \mathrm{E}, . . \quad . \quad .
$$

TABLE of the greatest admissible distances between the bearings of continaous shafts, sulject to no transverse strein except from their own weights; computed

\begin{tabular}{|c|c|c|}
\hline \multirow{2}{*}{ DIAMETER OF SHAFT, IN IXCIIES, } & \multicolumn{2}{|c|}{$\begin{array}{l}\text { Distance between bearings } \\
\text { in feet. }\end{array}$} \\
\hline & $\begin{array}{c}\text { If of } \\
\text { wrought iron }\end{array}$ & If of stcel \\
\hline 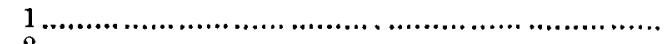 & $12 \cdot 27$ & $12 \cdot 61$ \\
\hline 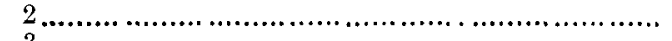 & $15 \cdot 46$ & $15 \cdot 89$ \\
\hline З & $17 \cdot 70$ & $18 \cdot 19$ \\
\hline 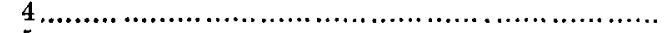 & 1948 & $20 \cdot 02$ \\
\hline 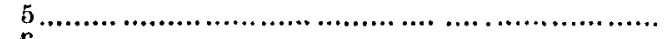 & $20 \cdot 69$ & $21 \cdot 57$ \\
\hline 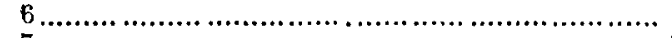 & $23 \cdot 30$ & $22 \cdot 92$ \\
\hline 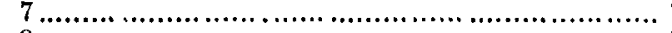 & $23 \cdot 48$ & $24 \cdot 13$ \\
\hline 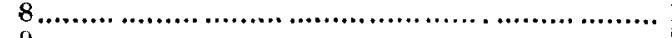 & $24 \cdot 55$ & $25 \cdot 23$ \\
\hline 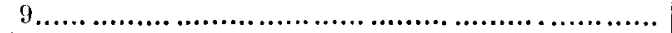 & $25 \cdot 53$ & $26 \cdot 24$ \\
\hline 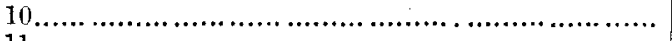 & $26 \cdot 44$ & $27 \cdot 18$ \\
\hline 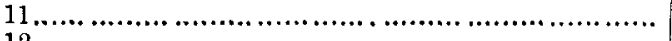 & $27 \cdot 30$ & $28 \cdot 05$ \\
\hline 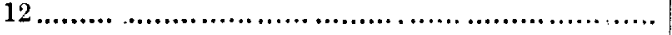 & $28 \cdot 10$ & $28 \cdot 88$ \\
\hline
\end{tabular}
by formula (7).

In practice, long shafts are scarcely ever entirely free from transverse strains; however, in the parts of long lines which have no pulleys or gears, with the couplings near the bearings, the interval 
between the bearings may approach the distances given in the preceding table. Near the extremities of a line, the distances between the bearings should be less than are given in the table. The last space should not exceed sixty per cent. of the distance there given, therdeflection in that space being much greater than in other parts of the line. In shafts moving with high velocities, it will usually be necessary to shorten the distances between the bearings, as given in the table, in order to obtain sufficient bearing surface to prevent heating.

In factories and workshops, power is usually taken off from the lines of shafting, at many points, by pulleys and belts, by means of which the machinery is operated. When the machines to be driven are below the shaft, there is a transverse strain on the shaft, due to the weight of the pulley and tension of the belt, which is in addition to the transverse strain due to the weight of the shaft itself. Sometimes the power is taken off horizontally on one side, in which case the tension of the belt produces a horizontal transverse strain; and the weight of the pulley acts with the weight of the shaft, to produce a vertical transverse strain. Frequently the machinery to be driven is placed above the floor to which the shaft is hung in the story below; in this case the transverse strain produced by the tension of the belt is in the opposite direction to that produced by the weight of the pulley and shaft. Sometimes power is taken off in all these directions, from the part of a shaft between two adjacent bearings. 'To transmit the same power, the necessary tension of a belt diminishes in proportion to its velocity; consequently, with pulleys of the same diameter, the transverse strain will diminish in the same ratio as the velocity of the shaft increases. In cotton and woollen factories with wooden floors, the bearings are usually hung on the beams, which are usually about eight feet apart; and a minimum size of shafting is adopted for the different classes of machinery which has been determined by experience as the least that will withstand the transverse strain. This minimum is adopted independently of the size required to withstand the torsional strain due to the power transmitted; if this requires a larger diameter than the minimum, the larger diameter is, of course, adopted. In some of the large cotton factories in this neighborhood, in which the bearings are about eight feet apart, a minimum diameter of $1 \frac{7}{8}$ inch was formerly adopted for the lines of shafting driving looms. In some mills this is still retained, in others $2 \frac{1}{8}$ inches and $2_{1}^{3}$ inches have been substituted. 
In the same mills, the minimum size of shafts driving spinning machinery, is from $2 \frac{1}{8}$ to $21 \frac{1}{6}$ inches. In very long lines of small shafting, fly-wheels are put on at intervals, to diminish the vibratory action due to the irregularities in the torsional strain.

We can deduce from formula (1) the breaking power, or, in other words, the power which, being transmitted by a shaft, will produce a torsional strain upon it equal to its total resistance to that force.

Put $p=$ the breaking power, in horse-powers of 33,000 foot-pounds,

$\mathrm{N}=$ the number of revolutions of the shaft per minute.

$$
p=\frac{2 \pi \mathrm{RNW}}{12 \times 33000}
$$

from which we deduce,

$$
\mathrm{WR}=\frac{12 \times 33000 p}{2 \pi \mathrm{N}}
$$

Substituting this value in (1), we find,

$$
p=\frac{\pi^{2} \mathrm{~N} d^{3} \mathrm{~T}}{8 \times 33000 \times 12}=0.000003115 \mathrm{~N} d^{3} \mathrm{~T}, \quad .
$$

Substituting the values of $\mathrm{x}$, adopted above for iron and steel, we have

$$
\begin{aligned}
& \text { For wrought iron, } p=0.1558 \mathrm{~N} d^{3}, \quad . \quad . \quad . \quad . \quad \text {. (9.) } \\
& \text { "steel, } \quad p=0.2492 \times d^{3}, \text {. . . . . (10.) }
\end{aligned}
$$

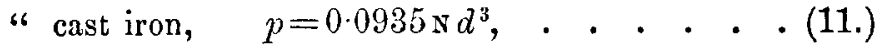

A formula for the wrought iron shafts of prime movers and other other shafts of the same material, subject to the action of gears, which I have adopted in numerous cases in practice during the last twenty years, and found to give an ample margin of strength, is

$$
d=\sqrt[3]{\frac{100 \mathrm{P}}{\mathrm{N}}, . .} \cdot \text {. . . . }
$$

in which $\mathrm{P}=$ the power transmitted, and from which we deduce

$$
\mathrm{p}=0.01 \mathrm{~N} d^{3}, \text {. . . . . . }
$$

For simply transmitting power, the formula $I$ have used is

from which we deduce

$$
d=\sqrt{\frac{50 \mathrm{P}}{\mathrm{N}}}, \cdot \cdot \cdot \cdot \cdot \cdot
$$

Comparing formulas (9) with (12) and (13), and also with (14) and (15), it will be seen that the formulas (12) and (13), used for shafts for prime movers, give a strength 15.58 times the breaking power; and the formulas (14) and (15), for shafts simply transmitting power, give a strength $7 \cdot 79$ times the breaking power. 
In applying the rules for the strength of materials to constructions in which there is no movement, it is usual to make the computed strength from three to five times the breaking strain. Bodies in rapid motion, however, usually require a greater margin of strength, in order to provide for the tendency to vibration. In cases where shafting for simply transmitting power, is very accurately finished and firmly supported by bearings at short intervals, an excess of strength two-thirds of that given by formulas (14), (19) and (23) will undoubtedly suffice. In ordinary cases, however, the strength given by these formulas should be adopted.

It must be understood that the shafts to which formulas (12) and (13) are applied, are supported by bearings sufficiently near to each other to guard against the transverse strain caused by the prime mover or gear.

To find formulas for steel shafts of the same strength as those for wrought iron, we have for prime movers $p=15.58 \mathrm{P}$; substituting this value of $p$ in $(10)$, we have

from which we deduce

$$
\mathrm{P}=0.016 \mathrm{~N} d^{3}, \cdot . \quad \cdot \quad \cdot(16,)
$$

$$
d=\sqrt{\frac{62 \cdot \overline{\mathrm{P}}}{\mathrm{N}}}, \cdot \cdot \cdot \cdot \cdot .
$$

Similarly, we find for steel shafts for simply transmitting power,

and

$$
\begin{aligned}
& \mathrm{P}=0.032 \mathrm{~N} d^{3}, . . . . . \\
& d=\sqrt[3]{\frac{31 \cdot 25 \mathrm{P}}{\mathrm{N}}}, \cdot \text {. . . . }
\end{aligned}
$$

Similarly for cast iron, we find for prime movers,

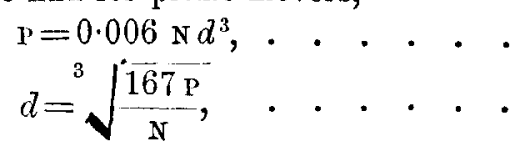

For simply transmitting power,

$$
\begin{aligned}
& \mathrm{p}=0.012 \mathrm{~N} d^{3}, \quad . \quad . \quad . \quad . \quad . \\
& a=\sqrt[3]{\frac{83 \mathrm{P}}{\mathrm{N}}}, \cdot . . . .
\end{aligned}
$$

The following table gives the power which can be safely carried by shafts making one hundred revolutions per minute. The power which can be carried by the same shafts at any other velocity, may be found by the following simple rule:

Multiply the power given in the table, by the number of revolutions made by the shaft per minute; divide the product by one hundred; the quotient will be the power which can be safely carried. 


\begin{tabular}{|c|c|c|c|c|c|c|}
\hline \multirow{2}{*}{$\begin{array}{l}\text { DIAMETER } \\
\text { IN } \\
\text { INCHES. }\end{array}$} & \multicolumn{3}{|c|}{$\begin{array}{l}\text { Horse-power which can be safely } \\
\text { carried by shafts for prime } \\
\text { movers and gears, well sup- } \\
\text { ported by bearings, and making } \\
\text { Jo0 revolutions per minute; } \\
\text { if of }\end{array}$} & \multicolumn{3}{|c|}{$\begin{array}{l}\text { Horse-power which can be safely } \\
\text { transmitted by shafts making } \\
100 \text { revolutions per minute, in } \\
\text { which the transverse strain, if } \\
\text { any, need not be considered; } \\
\text { if of }\end{array}$} \\
\hline & $\begin{array}{c}\text { Wrought } \\
\text { iron, } \\
\text { computed } \\
\text { by formula } \\
(13)\end{array}$ & $\begin{array}{c}\text { Steel, } \\
\text { computed } \\
\text { by } \\
\text { formula } \\
\text { (1ij) }\end{array}$ & $\begin{array}{l}\text { Cast Iron, } \\
\text { computed } \\
\text { by } \\
\text { formula } \\
(20)\end{array}$ & $\left|\begin{array}{c}\text { Wrought } \\
\text { Iron, } \\
\text { computed } \\
\text { by formula } \\
(15)\end{array}\right|$ & $\begin{array}{c}\text { Steel, } \\
\text { computed } \\
\text { by } \\
\text { formula } \\
\text { (18) }\end{array}$ & $\begin{array}{l}\text { Cast Iron, } \\
\text { computed } \\
\text { by } \\
\text { formula } \\
(22)\end{array}$ \\
\hline 1.00 & $1 \cdot(10$ & $1 \cdot 60$ & 0.60 & 2.00 & $3 \cdot 20$ & $1 \cdot 20$ \\
\hline 1.25 & $1 \cdot 95$ & $3 \cdot 12$ & $1 \cdot 17$ & $8 \cdot 10$ & $6 \cdot 24$ & $2 \cdot 34$ \\
\hline $1 \cdot 50$ & $8 \cdot 37$ & 569 & $2 \cdot 03$ & $6 \cdot 74$ & $10 \cdot 78$ & $4 \cdot 06$ \\
\hline 1.75 & $5 \cdot 36$ & $8 \cdot 58$ & $3 \cdot 2 \cdot 2$ & $10 \cdot 72$ & $17 \cdot 16$ & $6 \cdot 44$ \\
\hline $2 \cdot 00$ & 8.00 & $12 \cdot 80$ & $4 \cdot 80$ & $16 \cdot 00$ & $25 \cdot 60$ & $9 \cdot 60$ \\
\hline $2 \cdot 25$ & $11 \cdot 39$ & $18 \cdot 2 \cdot 2$ & 6.83 & $22 \cdot 78$ & $36 \cdot 44$ & $13 \cdot 66$ \\
\hline $2 \cdot 50$ & $15 \cdot 62$ & $24 \cdot 99$ & $9 \cdot 3 \pi$ & $31 \cdot 24$ & $49 \cdot 98$ & $18 \cdot 74$ \\
\hline $2 \cdot 75$ & $20 \cdot 80$ & $33 \cdot 28$ & $12 \cdot 48$ & $41 \cdot 60$ & $66 \cdot 56$ & $24 \cdot 96$ \\
\hline $3 \cdot 00$ & $2 \bar{\tau} \cdot 00$ & $43 \cdot 20$ & $16 \cdot 20$ & $54 \cdot 00$ & $86 \cdot 40$ & $32 \cdot 40$ \\
\hline $3 \cdot 25$ & $34 \cdot 38$ & $54 \cdot 93$ & $20 \cdot 60$ & $68 \cdot 66$ & $109 \cdot 86$ & $41 \cdot 20$ \\
\hline $3 \cdot 50$ & $42 \cdot 87$ & $68 \cdot 59$ & $25 \cdot 7 \cdot 2$ & $85 \cdot 74$ & $137 \cdot 18$ & 51.44 \\
\hline $3 \cdot 75$ & $52 \cdot 73$ & $84 \cdot 37$ & $31 \cdot 64$ & $105 \cdot 46$ & $168 \cdot 74$ & $63 \cdot 28$ \\
\hline $4 \cdot 00$ & 64.00 & $102 \cdot 40$ & $38 \cdot 40$ & 128.00 & 204.80 & 76.80 \\
\hline $4 \cdot 25$ & $76 \cdot 77$ & $122 \cdot 83$ & $46 \cdot 06$ & $153 \cdot 54$ & $245 \cdot 66$ & $92 \cdot 12$ \\
\hline $4 \cdot 50$ & $91 \cdot 12$ & 145.79 & $54 \cdot 67$ & $182 \cdot 24$ & $291 \cdot 58$ & $109 \cdot 34$ \\
\hline 4.75 & $107 \cdot 17$ & $171 \cdot 47$ & $64 \cdot 30$ & $214 \cdot 34$ & 34294 & $128 \cdot 60$ \\
\hline $5 \cdot 00$ & $125 \cdot 00$ & $200 \cdot 00$ & 75.00 & $250 \cap 0$ & $400 \cdot 00$ & $150 \cdot 00$ \\
\hline $5 \cdot 25$ & 144.70 & 231.52 & $86 \cdot 82$ & $289 \cdot 41)$ & $463 \cdot 04$ & $173 \cdot 64$ \\
\hline $5 \cdot 50$ & $16 t \cdot 3 \pi$ & $266 \cdot 19$ & 99.82 & 332.74 & $532 \cdot 38$ & $199 \cdot 64$ \\
\hline $5 \cdot 75$ & $190 \cdot 11$ & $304 \cdot 18$ & $114 \cdot 06$ & $380 \cdot 22$ & $608 \cdot 36$ & $228 \cdot 12$ \\
\hline $6 \cdot 00$ & 216.00 & $345 \cdot 60$ & $129 \cdot 60$ & 432.00 & $691 \cdot 20$ & $259 \cdot 20$ \\
\hline $6 \cdot 25$ & $244 \cdot 14$ & $390 \cdot 62$ & $146 \cdot 49$ & $488 \cdot 28$ & 781.24 & 292.98 \\
\hline $6 \cdot 50$ & $274 \cdot 62$ & $439 \cdot 39$ & $164 \cdot 78$ & $549 \cdot 24$ & $878 \cdot 78$ & $329 \cdot 56$ \\
\hline $6 \cdot 75$ & 307.55 & $402 \cdot 08$ & 184.53 & $615 \cdot 10$ & $984 \cdot 16$ & $369 \cdot 06$ \\
\hline $7 \cdot 00$ & $343 \cdot 00$ & $548 \cdot 80$ & $205 \cdot 80$ & 686.00 & $1097 \cdot 60$ & $411 \cdot 60$ \\
\hline $7 \cdot 25$ & 381.08 & $609 \cdot 73$ & $228 \cdot 65$ & $762 \cdot 16$ & $1219 \cdot 46$ & $457 \cdot 30$ \\
\hline $7 \cdot 50$ & $421 \cdot 87$ & $674 \cdot 99$ & $253 \cdot 13$ & $843 \cdot 74$ & $1349 \cdot 98$ & $506 \cdot 26$ \\
\hline $7 \cdot 75$ & $465 \cdot 48$ & 744.77 & 279.29 & $930 \cdot 96$ & $1489 \cdot 54$ & 558.58 \\
\hline $8 \cdot 00$ & $512 \cdot 00$ & 819.20 & $307 \cdot 20$ & $1024 \cdot 00$ & $1638 \cdot 40$ & 61440 \\
\hline $8 \cdot 25$ & 561.52 & $898 \cdot 43$ & 386.91 & $1123 \cdot 04$ & $1796-8 b$ & $673 \cdot 42$ \\
\hline $8 \cdot 50$ & $614 \cdot 12$ & $98 \cdot 2 \cdot 59$ & $368 \cdot 47$ & $12 \cdot 28 \cdot 24$ & $1965 \cdot 18$ & 736.94 \\
\hline $8 \cdot 75$ & $669 \cdot 92$ & $1071 \cdot 87$ & $401 \cdot 95$ & 1389.84 & $2143 \cdot 74$ & $803 \cdot 90$ \\
\hline 9.00 & $729 \cdot 00$ & $1166 \cdot 40$ & $437 \cdot 40$ & $1458 \cdot 00$ & $2332 \cdot 80$ & 874.80 \\
\hline $9 \cdot 25$ & $791 \cdot 45$ & $1266 \cdot 82$ & 474.87 & $1582 \cdot 90$ & $2532 \cdot 64$ & 949.74 \\
\hline $9 \cdot 60$ & $857 \cdot 37$ & 1871.79 & $514 \cdot 43$ & $1714 \cdot 74$ & $2743 \cdot 58$ & 102886 \\
\hline $9 \cdot 75$ & $926 \cdot 86$ & 1482.98 & $556 \cdot 12$ & $1853 \cdot 72$ & 2965.96 & $1112 \cdot 24$ \\
\hline 10.00 & 1000.00 & $1600 \cdot 00$ & $600 \cdot 00$ & $20 \backsim 000$ & $3200 \cdot 00$ & $1200 \cdot 00$ \\
\hline
\end{tabular}


Comparing formulas (14) and (19), it will be seen that the diameters of shafts of wrought iron and steel, to transmit the same power, are in the ratio of the cube root of 50 to the cube root of $31 \cdot 25$, or as 1 to 0.855 . The weights of the shafts will be as the squares of the diameters, or as 1 to 0.731 . The power required to overcome the friction of the shafts in their bearings, assuming that the co-efficient of friction is the same for wrought iron and steel, will be as the products of the weights into the velocities of the rubbing surfaces. The number of revolutions in a given time being the same in both, the velocities of the rubbing surfaces will be as the diameters; and the weights will be as the squares of the diameters; the power required to overcome the friction will therefore be as the cubes of the diameters, or as 1 to 0.625 . That is to say, the power which must be expended to overcome the friction of a steel shaft is five-eighths of that required to overcome the friction of a wrought iron shaft of equal strength.

The superiority of steel to resist transversal strain is much less than to resist torsional strain. The relative diameters of wrought iron and steel shafts, to resist equal transverse strains, exclusive of their own weights, are inversely as the fourth roots of the respective values of $\mathrm{E}$, or as $\left(\frac{1}{3500000}\right)^{\frac{1}{4}}$ to $\left(\frac{1}{3800000}\right)^{\frac{1}{4}}$, or as 1 to 0.98 . 'That is to say, stcel shafts, to offer the same resistance to external transverse strains, may be two per cent. less in diameter than wrought iron shafts. The weights of such steel shafts will be about four per cent. less than the weights of wrought iron shafts of equal stiffness; and the power required to overcome the friction of the bearings will be about 6 per cent. less.

Lowell Mass., May 4, 1867.

(Continued from page 304.)

\section{THE NEW YORK "CENTRAL PARK."}

By Wildiam H. GRANT, Superintending Engineer.

SHoUld such an amount of rain fall at a time when the grounds were covered with a considerable body of snow, and the grounds not frozen, the accumulation of water might so much surpass the capacity of the gutters and drains, as to cause the gullying of the roads and grounds. But the simultaneous occfrence of such contingencies, 